\title{
ФІЗИЧНИЙ МЕХАНІЗМ НАБУХАННЯ КЕРАТИНУ
}

\section{Л.А. БУЛАВІН, ${ }^{1}$ Ю.Ф. ЗАБАШТА, ${ }^{1}$ А.В. КАСПРОВА, ${ }^{1}$ С.П. СЕНЧУРОВ ${ }^{1}$ Ю.Є. ГРАБОВСЬКИЙ, ${ }^{1}$ С.О. АЛЄКСЕЄВ ${ }^{2}$}

\author{
${ }^{\mathbf{1}}$ Київський національний університет ім. Тараса Шевченка, фізичний факультет \\ (Вул. Володимирсъка, 64, Київ, МСП 01601; е-таil: \\ zabashta@mail. univ. kiev. ua,kasprova. a@gmail. com, sergsenc@mail. univ. kiev.ua)
}

УДК 538.91

${ }^{2}$ Київський національний університет ім. Тараса Шевченка, хімічнийний факультет

Досліджено механізм набухання кератину у водному розчині тіогліколевої кислоти. Отримано рентгенівські рефлектограми та ІЧ-спектри, залежність акустичного модуля від статичного напруження для ненабухлого та набухлого кератину. На основі цих експериментальних даних встановлено, що при набуханні кератину молекули тіогліколевої кислоти розташовуються у внутрішньофібрилярних невпорядкованих областях, приводячи до орієнтації спіральних сегментів. При цьому між орієнтованими сегментами виникають нові дисульфідні зв'язки, які фіксують новоутворену структуру.

\section{1. Вступ}

Кератин - речовина, що відноситься до класу фібрилярних білків. Сучасні погляди на структуру кератину викладені в [1-4] (див. рис. 1). Елементом стру-

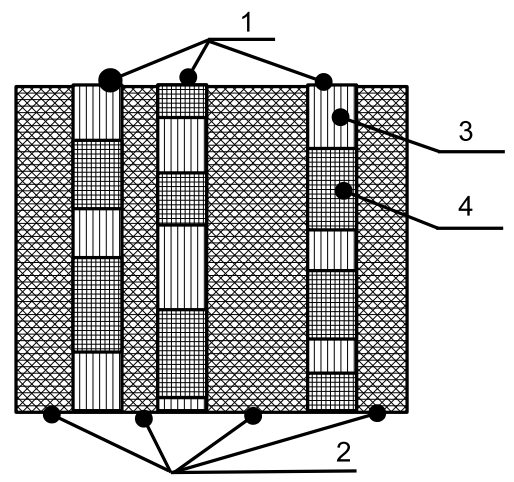

Рис. 1. Структура кератину: 1 - фібрили, 2 - міжфібрілярні невпорядковані області, 3 - кристаліт, 4 - внутрішньофібрилярна невпорядкована область ктури кератину є фібрила, діаметр якої становить 7,5 нм. Фібрили відділені одна від одної міжфібрилярними невпорядкованими прошарками, що мають назву аморфного матрикса, i їх осі розташовані паралельно. Уздовж фібрили чергуються одна з одною впорядковані та внутрішньофібрилярні невпорядковані області.

Впорядкована область є кристалічною граткою, утвореною кератиновими ланцюгами, осі яких направлено паралельно осі фібрили. Ці ланцюги мають форму $\alpha$-спіралі, відстань між сусідніми витками якої становить приблизно 0,51 нм (рис. 2,a). Ланцюги між собою з'єднуються хімічними (дисульфідними) та водневими зв'язками.

У невпорядкованих областях ці зв'язки розірвані або суттєво послаблені порівняно 3 кристалічними. Ланцюги в таких областях є послідовністю спіральних та неспіральних сегментів (рис. 2,б).

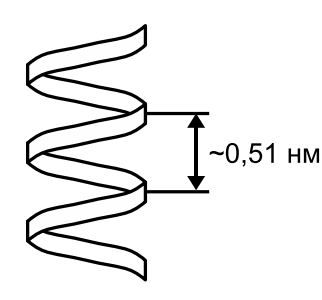

a

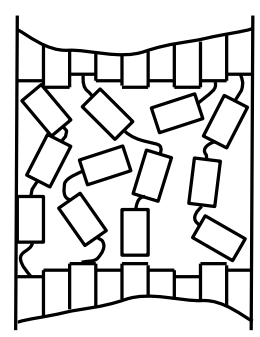

6
Рис. 2. Форма кератинових ланцюгів: $a-$ у впорядкованих, $б$ - у невпорядкованих внутрішньофібрилярних областях. Спіральні сегменти зображено прямокутниками, неспіральні звивистими лініями 

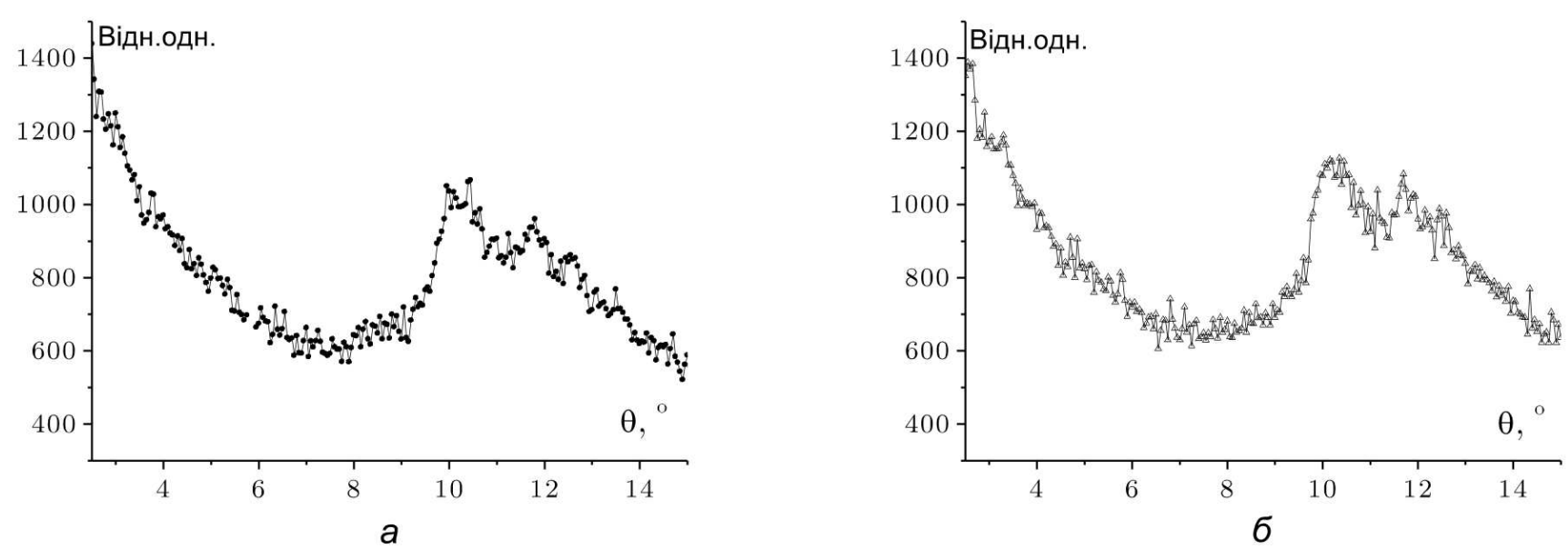

Рис. 3. Кутова залежність інтенсивності дифрагованого рентгенівського випромінювання на необроблених (а) та оброблених (б) зразках. Орієнтація осі зразків по меридіану

Традиційно при експериментальному вивченні властивостей кератину об'єктом дослідження вибирають людський волос. Явище набухання кератину покладено в основу технології, призначеної для надання волосу вигнутої форми [5]. Однією з рідинних систем, які використовуються у цій технології є водний розчин тіогліколевої кислоти. Мета даної роботи - визначити фізичний механізм набухання кератину у водному розчині тіогліколевої кислоти. Іншими словами, ми намагатимемось визначити структурні зміни, що відбуваються у кератині при його набуханні. Як відомо авторам, це питання раніше в літературі не розглядалось.

\section{2. Підготовка зразків для дослідження}

Дотримуючись традиції, об'єктом дослідження є людський волос. Середній діаметр волосини становить $d=69$ мкм.

Досліджували два типи зразків, які умовно названо необроблені та оброблені. Необроблені зразки являли собою свіжозрізане волосся. Оброблені зразки було одержано витримуванням у водному розчині тіогліколевої кислоти об'ємною концентрацією $10 \%$ при температурі $35{ }^{\circ} \mathrm{C}$ протягом 10 хв. Після виймання iз розчину зразки промивали дистильованою водою i висушували.

\section{3. Ширококутова рентгенографія кератину}

Зразками для рентгенографічного дослідження були пучки волосся діаметром 6 мм. Ці пучки прикріплю- вались до кварцової кювети, яку було розміщено у рентгенівському дифрактометрі ДРОН-3М.

На рис. 3 показано рентгенівські дифрактограми необроблених та оброблених зразків для випадку меридіанної дифракції. Згідно з цим рисунком для необроблених зразків меридіанний рефлекс спостерігається під кутом $\theta_{1}=9,9^{\circ}$, а для оброблених зразків $-\theta_{1}^{\prime}=10,3^{\circ}$. Цим значенням кутів відповідають відстані $d_{1}=0,518$ нм і $d_{1}^{\prime}=0,501$ нм. Точність визначення кута $\Delta \theta=0,1^{\circ}$. Отже, з достовірністю можна стверджувати, що після обробки змінюється положення меридіанного рефлексу.

Як відомо [1], меридіанний рефлекс відповідає відстані між сусідніми витками $\alpha$-спіралі у кристаліті. Грунтуючись на даних, наведених на рис. 3, можна стверджувати, що при набуханні кератину відстань між сусідніми витками $\alpha$-спіралі у кристаліті зменшується.

На нашу думку, при встановленні структурних змін, викликаних набуханням, першочергове завдання полягає у пошуку відповіді на запитання про місця локалізації молекул тіогліколевої кислоти. Саме на це конкретне запитання і спробуємо дати відповідь, Ірунтуючись на даних проведеного рентгенографічного дослідження.

Ситуацію дещо спрощує наявність у кератині значної кількості невпорядкованої речовини. Зрозуміло, що молекулам тіогліколевої кислоти вигідніше осідати у невпорядкованих областях, бо це супроводжується меншим зростанням енергії системи.

Проведений експеримент зайвий раз підтверджує цей майже очевидний висновок. Дійсно, нехай деяка молекула тіогліколевої кислоти занурилась у гратку. 


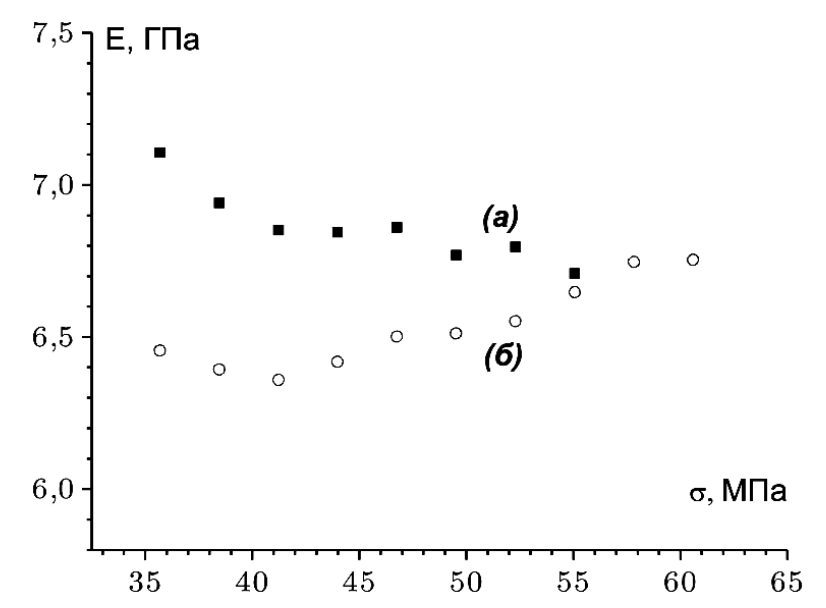

Рис. 4. Залежність модуля Юнга $E$ від статичного напруження $\sigma$ ( $a$ - для необроблених, $\sigma$ - для оброблених зразків)

Після видалення цієї молекули у гратці залишається порожнина, яка фактично відіграє роль точкового дефекту гратки. Відомо, що на положення рефлексу такі дефекти не впливають, їх поява може лише змінити інтенсивність рефлексу; при великій кількості дефектів може зрости ступінь розмитості рефлексу. Однак в експерименті ми не спостерігаємо такого зростання після обробки, що зайвий раз переконує в тому, що кристаліти залишаються практично недоступними для молекул тіогліколевої кислоти. До такого ж висновку дійшли автори роботи [6].

Поставлене питання тепер зводиться до розв'язання дилеми: у внутрішньофібрилярних невпорядкованих областях чи в міжфібрилярних невпорядкованих прошарках розташовуються молекули тіогліколевої кислоти.

Як відомо, зміна параметрів кристалічної гратки може бути викликана або фазовим переходом, або виникненням макроскопічних напружень.

Існує також інша кристалічна модифікація кератину - так звана $\beta$-форма [5]. Однак рефлекси, отримані нами для обробленого волокна, відрізняються від рефлексів, характерних для $\beta$-форми кератину.

Таким чином, результати даного експерименту приводять до висновку, що в оброблених зразках уздовж осі фібрил діє стискаюче напруження, яке спричиняє зменшення відстані між сусідніми витками $\alpha$-спіралі у кристаліті.

Тим самим ми отримуємо відповідь на поставлене запитання, оскільки таке напруження може виникнути лише у випадку, коли молекули тіогліколевої кислоти розташуються у внутрішньофібрилярних невпорядкованих областях.

\section{4. Акустичні характеристики кератину}

Для вимірювання акустичних характеристик кератину використовували метод акустичної інтерферометрії [7]. Частота становила $f=12930$ Гц. Вимірювали швидкість звуку $с$ при різних значеннях статичного напруження $\sigma$. Виміри проводили при температурі $T=153 K$, щоб виключити можливий вплив релаксаційних процесів на результати вимірювань.

За формулою

$E=\rho c^{2}$

де $\rho$ - густина, визначався модуль пружності $E$.

Згідно з роботою [8] залежність $E(\sigma)$ записували у вигляді

$E=E_{0}+\frac{E_{0}^{\prime}}{E_{0}} \sigma$

де $E_{0}$ i $E_{0}^{\prime}$ - модулі другого та третього порядків.

На рис. 4 подано залежність модуля Юнга $E$ від статичного напруження $\sigma$ для необроблених та оброблених зразків. Як видно з рис. 4, після обробки кератину:

1) модуль пружності зменшується;

2) змінюється знак модуля третього порядку: для необроблених зразків він від'ємний, для оброблених - додатний.

Подивимось, як вказані факти узгоджуються з раніше наведеною моделлю структури.

Міжфібрилярні невпорядковані області фактично являють собою перехідні шари. Тому їх товщина суттєво менша за розміри інших структурних областей. Завдяки останній обставині ці шари мало впливатимуть на пружні характеристики волокна, і при розгляді даних акустичного експерименту можна не зважати на наявність таких перехідних шарів, вважаючи, що досліджувана система є сукупністю областей двох типів: невпорядкованих внутрішньофібрилярних та впорядкованих фібрилярних областей.

Позначимо через $E_{1}$ та $E_{2}$ модулі пружності згаданих областей, через $\kappa-$ відносний об'єм, зайнятий невпорядкованими областями. Нехтуючи взаємодією між фібрилами, будемо вважати, що в загальну деформацію кожна фібрила робить незалежний внесок. У фібрилі впорядковані та невпорядковані області розташовуються послідовно. Це означає, що піддатливість фібрили є сумою піддатливостей окремих областей і виражається формулою

$\frac{1}{E}=\frac{\kappa}{E_{1}}+\frac{1-\kappa}{E_{2}}$ 
У впорядкованих областях осі ланцюгів розташовані уздовж осі волокна, у невпорядкованих - ланцюги розорієнтовані. Завдяки цьому слід вважати, що

$E_{1} \ll E_{2}$.

Розміри невпорядкованих внутрішньофібрилярних та впорядкованих областей - величини одного порядку. Наближено вважаючи ці величини рівними, отримуємо із формули (3), враховуючи нерівність (4), вираз

$E \approx 2 E_{1}$

тобто виміряний акустичний модуль пружності виступає подвоєним модулем пружності невпорядкованих областей.

Раніше було наголошено на двох фактах, виявлених акустичним експериментом. Перший факт зменшення модуля пружності після обробки - тепер можна розглядати як наслідок зменшення модуля пружності невпорядкованих областей.

У поєднанні з даними рентгенографічного експерименту така інтерпретація виглядає логічною. Дійсно, як показав рентгенографічний експеримент, молекули тіогліколевої кислоти розміщуються у невпорядкованих областях (рис. 5,a). Після видалення цих молекул у невпорядкованих областях залишаються порожнини (рис. 5,б). I саме наявність цих порожнин і спричиняє зменшення модуля невпорядкованих областей.

Другий факт, виявлений акустичним експериментом - зміна знака модуля третього порядку - також знаходить своє пояснення в моделі структурних змін, зображеній на рис. 5,б. Дійсно, в статті [8] показано, що від'ємний знак модуля третього порядку характерний для неорієнтованих структур. Натомість, додатний знак цього модуля притаманний орієнтованим. Отже, можна стверджувати, що внаслідок обробки частина спіральних сегментів у внутрішньофібрилярних невпорядкованих областях орієнтується вздовж осі фібрили, як це показано на рис. 5,6 .

\section{5. Інфрачервоні спектри кератину}

Інфрачервоні спектри було отримано за допомогою приладу Nicolet 4700/6700 FT-IR.

На рис. 6, $a$ наведено IЧ-спектри оброблених та необроблених зразків. На рис. 6,б показано низькочастотну ділянку цього спектра. Як видно з рисунка,

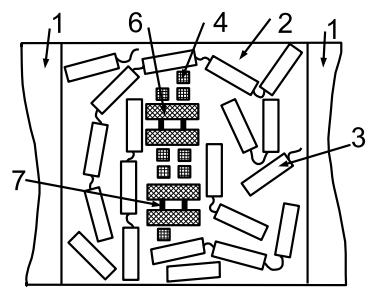

a

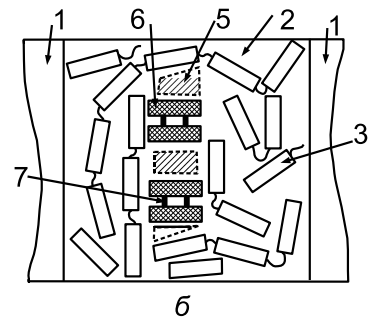

6
Рис. 5. Структура внутрішньофібрилярної невпорядкованої області: $a$ - при набуханні, $\sigma$ - після промивки та висушування; 1 - впорядкована область, 2 - внутрішньофібрилярна невпорядкована область, 3 - неорієнтований спіральний сегмент, 4 - молекула тіогліколевої кислоти, 5 - порожнина, 6 - орієнтований спіральний сегмент, 7 - новий дисульфідний зв'язок, що з'єднує орієнтовані сегменти

обробка приводить до появи смуги поглинання на частоті $520 \mathrm{~cm}^{-1}$. У літературі [9] цю смугу приписують коливанням, які виникають при утворенні дисульфідним зв'язком із сусідніми зв'язками ланцюгів конфігурацій "гош-транс-гош".

Поява смуги $520 \mathrm{~cm}^{-1}$ є ще одним аргументом на користь пропонованого механізму структурних змін. Дійсно, як це показано на рис. 5, в областях, що розмежовують порожнини, осі спіральних сегментів розташовуються паралельно один до одного. Тому між ними можуть виникнути дисульфідні зв'язки (на рис. 5 вони умовно зображені товстими лініями). Однак, незважаючи на паралельне розташування осей спіральних сегментів, їх атоми не утворюють гратки, тому конфігурація, утворена дисульфідним зв'язком із сусідніми зв'язками ланцюгів буде відрізнятись від конфігурації, характерної для гратки. Саме тому згадана смуга відсутня у спектрі необробленого зразка.

Завдяки новоутвореним дисульфідним зв'язкам нова структура, що характеризується наявністю орієнтованих спіральних сегментів у внутрішньофібрилярних невпорядкованих областях, зберігається після видалення молекул тіогліколевої кислоти.

\section{6. Висновки}

Для фізичного механізму набухання кератину у водному розчині тіогліколевої кислоти характерні такі особливості:

1) молекули тіогліколевої кислоти розташовуються у внутрішньофібрилярних невпорядкованих областях; 2) поява цих молекул у згаданих областях приводить до орієнтації частини спіральних сегментів кератинових ланцюгів в околі вказаних молекул; 


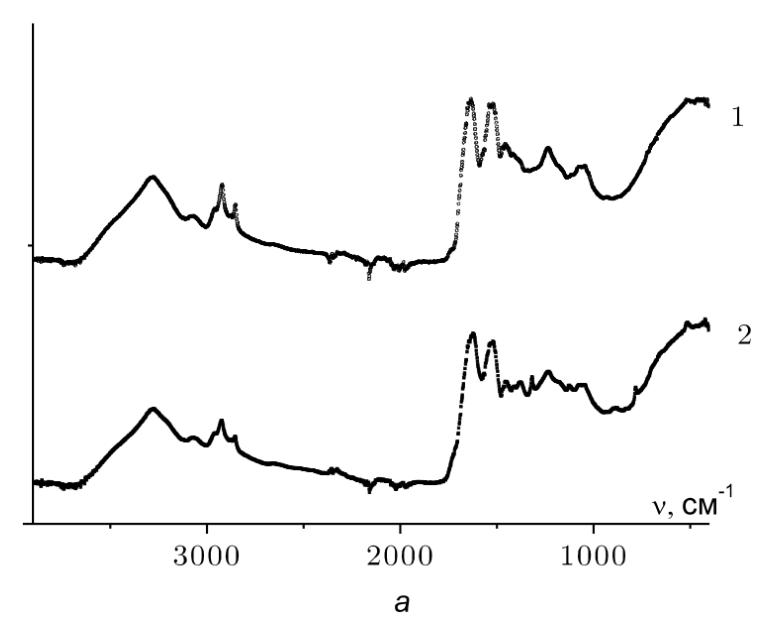

Рис. 6. Інфрачервоні спектри необроблених (1) та оброблених

3) між орієнтованими спіральними сегментами виникають нові дисульфідні зв'язки, завдяки чому новоутворена структура кератину зберігається після видалення молекул тіогліколевої кислоти.

1. C.R. Robbins, Chemical and Physical Behavior of Human Hair (Springer, New York, 2002).

2. M. Feughelman, Mechanical Properties and Structure of Alpha-Keratin Fibres: Wool, Human Hair and Related Fibres (UNSW Press, Sydney, 1997).

3. D.S. Fudge and J.M. Gosline, Proc. R. Soc. Lond. B 271, 291 (2004).

4. C. Popescu and H. Höcker, Chem. Soc. Rev. 36, 1282 (2007).

5. D.L. Nelson and M.M. Cox, Lehninger Principles of Biochemistry (W.H. Freeman, New York, 2004).

6. N. Nishikawa, Yo. Tanizawa, Sh. Tanaka, Ya. Horiguchi, and T. Asakura, Polymer 39, 3835 (1998).

7. В.Ф. Ноздрев, Н.В.Федорищенко, Молекулярная акустика (Высшая школа, Москва, 1974).

8. Ю.С. Голик, Ю.Ф. Забашта, В.Н. Махровский, Акуст. журн. 3, 543 (1992).

9. R. Paquin and Ph. Colomban, J. Raman Spectrosc. 38, 504 (2005)

Одержано 03.08.11

\section{ФИЗИЧЕСКИЙ МЕХАНИЗМ НАБУХАНИЯ КЕРАТИНА}

Л.А. Булавин, Ю.Ф. Забашта, А.В. Каспрова,

С.П. Сенчуров, Ю.Е Грабовский, С.А. Алексеев

$\mathrm{P}$ е $з$ ю м е

Исследуется механизм набухания кератина в водном растворе тиогликолевой кислоты. Получены рентгеновские дифракто-

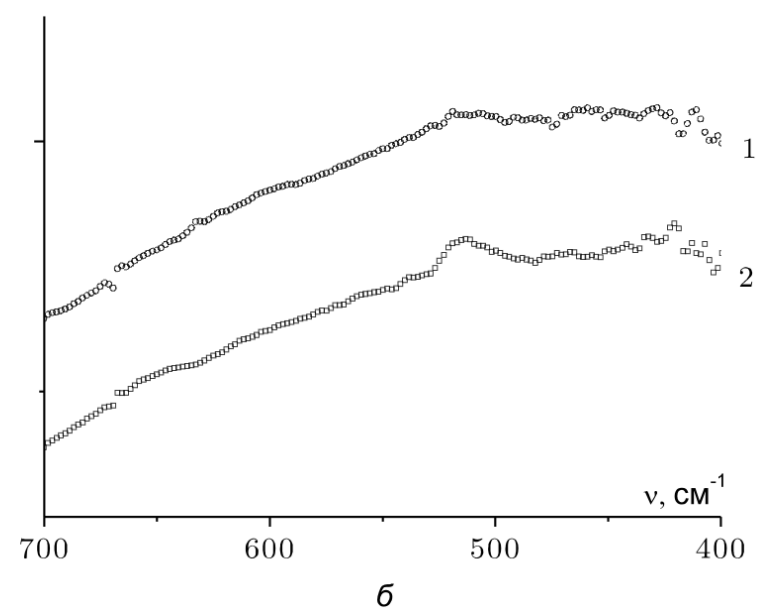

(2) зразків

граммы и ИК-спектры, зависимость акустического модуля от статического напряжения для ненабухшего и набухшего кератина. На основе экспериментальных данных установлено, что при набухании кератина, молекулы тиогликолевой кислоты располагаются во внутрифибриллярных неупорядоченных областях, приводя к ориентации спиральные сегменты. При этом между ориентированными сегментами возникают новые дисульфидные связи, которые фиксируют новообразованную структуру.

\section{PHYSICAL MECHANISM OF KERATIN SWELLING}

L.A. Bulavin ${ }^{1}$, Yu.F. Zabashta ${ }^{1}$, A.V. Kasprova ${ }^{1}$, S.P. Senchurov ${ }^{1}$, Yu.E. Grabovskii ${ }^{1}$, S.O. Alekseev ${ }^{2}$

${ }^{1}$ Taras Shevchenko National University of Kyiv, Faculty of Physics

(64, Volodymyrs'ka Str., Kyiv 01601, Ukraine; e-mail: zabashta@mail.univ.kiev.ua,kasprova.a@gmail.com, sergsenc@mail.univ.kiev.ua),

${ }^{2}$ Taras Shevchenko National University of Kyiv, Faculty of Chemistry

(64, Volodymyrs'ka Str., Kyiv 01601, Ukraine)

$\mathrm{S} \mathrm{u} \mathrm{m} \mathrm{m} \mathrm{a} \mathrm{r} \mathrm{y}$

The mechanism of swelling of keratin in an aqueous solution of thioglylicolic acid has been studied. X-ray diffractograms, IRspectra, and the dependence of the acoustic modulus on the static tension in nonswollen and swollen keratin fibers are obtained. Based on experimental data, we found that the molecules of thioglycolic acid are arranged in unordered intrafibrillar regions at the swelling of keratin, which stimulates the orientation of spiral segments. Disulfide bonds between oriented segments appear to fix the newly formed structure. 